Тупиця О. Специфіка перекладу безеквівалентних лексичних одиниць...

УДК 81'373:81'25

DOI 10.24919/2411-4758.2017.110622

олександр ТУПИЦЯ, кандидат філологічних наук, доцент кафедри украӥнської та іноземних мов, Полтавський університет економіки і торгівлі

(Украӥна, Полтава) tupytsya@ukr.net orcid.org/0000-0002-6329-7011

\title{
СПЕЦИФІКА ПЕРЕКЛАДУ БЕЗЕКВІВАЛЕНТНИХ ЛЕКСИЧНИХ ОДИНИЦЬ ПОЕТИЧНОГО ТЕКСТУ
}

У статті з'ясовано й доповнено визначення явища безеквівалентності в лексичній системі мови. На основі аналізу поетичних контекстів та іншомовних текстів-перекладів визначено безеквівалентну лексику як один із видів сильних позицій. Зіставлення іншомовних контекстів дало змогу з'ясувати композиційну роль безеквівалентної лексики в поетичному тексті як сильної позиції, щуо створює етнокультурну картину світу в межах поетичної моделі. Виявлена специфіка безеквівалентних лексичних одинищь визначає особливості їх перекладу.

Ключові слова: поетичний текст; мовна картина світу; композиція поетичного тексту; сильні позиції; безеквівалентна лексика.

Лim. 14.

Александр ТУПИЦА, кандидат филологических наук, доцент кафедры украинского и иностранных языков, Полтавский университет экономики и торговли (Украина, Полтава) tupytsya@ukr.net

\section{СПЕЦИФИКА ПЕРЕВОДА БЕЗЭКВИВАЛЕНТНЫХ ЛЕКСИЧЕСКИХ ЕДИНИЦ ПОЭТИЧЕСКОГО ТЕКСТА}

В статье определено и дополнено определение явления безэквивалентности в лексической системе языка. На основе анализа контекстов и иностранных текстов-переводов выделено безэквивалентную лексику как один из видов сильных позиций. Сравнения иноязычных контекстов дало возможность для определения композиционной роли безэквивалентной лексики в поэтическом тексте как сильной позиции, которая создаёт этнокультурную картину мира в рамках поэтической модели. Такая специфика безэквивалентных лексических единии определяет особенности их перевода.

Ключевые слова: поэтический текст; языковая картина мира; композиция поэтического текста; сильные позицин; безэквивалентная лексика.

Лит. 14. 
Постановка проблеми. Національно-мовний образ світу виявляється на різних мовних рівнях: в особливостях евфонічних засобів, морфолого-словотвірних одиницях, символізації окремих лексичних одиниць тощо. Мовна картина світу найповніше виражається в лексико-семантичній системі мови. Особливою одиницею, здатною відображати національно-культурну своєрідність мови на лексичному рівні, вважають безеквівалентну лексику (далі БЛ).

Безеквівалентні лексичні одиниці називають специфічні поняття, притаманні лише певним мовам; саме тому їх значення для втілення картини світу тексту надзвичайно важливе, особливої уваги заслуговує проблема «неперекладності». Дослідники звернули увагу, що національно-культурний компонент лексичного значення актуалізується в межах тексту і поширюється на семантику інших одиниць (С.Я. Ермоленко, В.І. Кононенко, А.К. Мойсієнко та ін.). Ці особливості функціонування національно маркованої лексики в художньому творі на сьогодні ще не достатньо вивчені, особливо в тексті поетичному. У лінгвістичній літературі неодноразово підкреслювалось, що в композиції поетичних текстів наявні домінанти, на які, головним чином, слід орієнтуватися при перекладі, але специфічних рис БЛ як смислової одиниці не визначено.

Аналіз досліджень. У сучасній мовознавчій науці існує концепція мовної картини світу, що відображає взаємозв'язки мови та культури. Українська мова виконує культурологічну функцію і формує національно-мовну картину світу українського етносу (3.С. Василько, Л.М. Дяченко, В.І. Кононенко, М.П. Кочерган, А.К. Мойсієнко та ін.) $[3 ; 5 ; 7 ; 9 ; 11]$.

Мовна картина світу, на думку багатьох учених, - це певний інваріант, що складається з варіантів, а саме: наукової, художньої, релігійної, етнічної картин світу тощо. Існування цих варіантів реалізується в різних видах текстів, які можна вважати конкретними проявами загальної картини світу. У художній картині світу можна виділити поетичну модель (поетичну картину світу), своєрідність якої полягає в здатності моделювати не лише об'єктивну дійсність, а й суб'єктивне ставлення до неї (Н.С. Богаткіна, А.К. Мойсієнко, І.Г. Торсуєва, С.В. Форманова та ін.) $[2 ; 11 ; 12 ; 14]$. У межах поетичної картини світу здатні, у свою чергу, до відображення епічна, етнічна, релігійна та інші картини світу через своєрідні образи, закодовані в змісті твору.

Дослідження особливостей явища безеквівалентності в лексичних системах різних мов набуло сьогодні великого значення в працях багатьох мовознавців (А.В. Волошина, Л.М. Дяченко, Н.Ф. Зайченко, О.В. Коваль-Костинська, О.Л. Паламарчук, Т.А. Космеда, М.П. Кочер- 
ган, О.І. Кремльова та ін.) [4; 5; 6; 8; 9; 10]. Ми також розглядали явище безеквівалентності в лексичній системі мови, аналізували проблеми іншомовного відтворення (перекладу) [13].

Мета статті полягає у визначенні ролі БЛ як одного з видів сильних позицій у композиції поетичного твору, з'ясуванні функціонально-семантичних властивостей таких лексичних одиниць, що дає можливість 3’ясувати специфіку перекладу БЛ іншими мовами.

Виклад основного матеріалу. Поетичний текст - система, що має цілий ряд відмінностей порівняно з іншими видами текстів. Ця своєрідність виявляється як в естетичному, так і в інформаційному та інших планах. Поетичний текст, з одного боку, - особлива система, організована за принципами структурності, ієрархічності, цілісності, з іншого явище естетичне. У композиції поезії емоційно-експресивні та образні функції здатні виконувати семантично нейтральні в непоетичному тексті лексичні одиниці (В.В. Виноградов, Ю.М. Лотман, Р.О. Якобсон).

Поетичний текст - система смислових елементів, які функціонально об'єднані в єдину ієрархічну структуру. Смислова структура виникає на основі сильних позицій, що у взаємодоповнюваності вибудовують смислову цілісність тексту (смисл-зміст). Це зумовлюється специфікою організації тексту поезії, що забезпечує акцентуалізацію найважливіших смислів.

У поетичному тексті наявні «сильні позиції» (далі СП) - домінанти тексту, що є наслідком специфічної організації, яка забезпечує висунення на перший план найважливіших смислів, зосередження уваги на головному, посилення емоційного та естетичного ефекту, виділення значущих зв язків між елементами суміжними та дистантними, які належать одному чи різним рівням, забезпечення єдності тексту та його відтворення [1, 12].

3 погляду сучасної лінгвістичної науки, поетичний текст - це складна побудова змісту. Усі елементи поетичного тексту наділені певним смисловим навантаженням, вони формують новий, неможливий за межами поетичної структури, зміст. Поетична структура у своїй основі виділяється ієрархією рівнів, елементи якої пов'язані між собою. Розуміння змісту поетичного твору грунтується на вивченні його елементів та взаємозв' язку між ними. Кожен поетичний твір - це мікросвіт, який вимагає тлумачення, декодування, розкриття підтексту та асоціацій, а вже потім можна говорити про його переклад.

Сильна позиція - окремий образ-смисл поетичного тексту, під яким розуміють таку логічну структуру, що створює у свідомості людини відображення позамовної дійсності; це носій інформації, смислова одиниця тексту. 
Лексична одиниця здатна посідати сильну позицію завдяки факторам, що стосуються: 1) місця в композиції поетичного тексту; 2) значення в системі тексту. СП знаходиться в композиції поетичного тексту в стані постійної готовності до актуалізації, вона характеризується здатністю до виявлення потенційних смислів, до семантичної трансформації. Декодування СП сприяє розкриттю потенційно закодованих сюжетів тексту, символічних значень окремих образів тощо. Характеризуючись синкретичністю й аналітичністю водночас, семантика окремої сильної позиції здатна розширювати межі тексту, надаючи окремим фрагментам емоційного й аксіологічного вимірів.

Семантика окремої сильної позиції - текстотвірна й образотворча величина, включена в процес взаємодії елементів текстової композиції, у результаті чого відбувається смислова переструктуалізація тексту, а отже, й вибудова значень. Стикування різнопланових елементів виявляє нові художньо-образні значення смислових елементів твору.

БЛ формально належить до групи смислових СП, оскільки висуваючись у сильну позицію композиції поетичного твору, вносить у зміст тексту сему «національне» - асоціативні зв'язки з певними історичними подіями, особами; неповторні символи, що характеризують особливості етнокультури; предметний світ, невідомий носіям іншої культури тощо. Сема «національне» поширюється на весь текст, оскільки усі елементи поетичного твору, що перебувають у СП (у тому числі й БЛ), вступають у суперструктурні кореляції. У поетичному тексті кодується етнічна картина світу. БЛ виступає формальним показником етнокультурної ідентифікації твору. Сильна позиція БЛ у композиції поетичного тексту визначається, у першу чергу, іiі впливом на смислову ієрархію.

Спостереження над БЛ у композиції поетичного тексту переконують у доцільності розмежування іiі за функціонально-семантичними ознаками на: 1) власні назви; 2) слова-символи; 3) слова-реалії.

Причини висування БЛ у СП можуть бути різними. Основними вважають: 1) незвичність. Тобто, безеквівалентна лексема означає поняття, невідоме читачеві, і тому потребує певних зусиль для декодування значення слова; 2) зв'язок із національною культурою. Значення багатьох БЛ зрозуміле носіям мови, оскільки більшість із них є цілком традиційними, означають звичні поняття, що стосуються певного етносу. Такі безеквівалентні одиниці сприяють оформленню «національної ідентифікації» твору, тобто виступають тим чинником, який дає можливість віднести окремий текст до певної культури.

СП безеквівалентних одиниць, у свою чергу, можуть мати «різний ступінь прояву». Тобто, СП цих одиниць визначається їх націо- 
нально-культурним значенням (висування зумовлене символічним, етнолінгвістичним та іншими значеннями). Але, з іншого боку, БЛ, перебуваючи в композиції поетичного тексту, може потрапляти у різні позиції, які самі вже визначаються як СП (висування зумовлене композицією тексту, коли мовні одиниці виділяються вже внаслідок свого розташування). Таким чином, СП безеквівалентних одиниць може також посилюватися внаслідок їх розташування в «ключових позиціях тексту».

Отже, БЛ у композиції поетичного твору висувається в СП, оскільки вступає в смислові зв'язки 3 іншими композиційними та смисловими домінантами тексту. Семантика БЛ («етнокультурне значення») поширюється на інші смисли, а частіше на зміст усього тексту, сприяючи ідентифікації певного тексту з культурним середовищем (виникнення етнічної картини світу). БЛ у композиції поетичного тексту виступає своєрідними сигналом, який розгортається в смисловій ієрархії твору, сприяє виникненню асоціативних зв'язків з певним етносом. Ці зв'язки виникають через те, що до складу БЛ належать національно марковані лексичні одиниці (у структурі лексичного значення БЛ наявна етнокультурна інформація): власні назви, слова-символи, реалії.

Дослідивши різні способи перекладу слів із національно-культурною семантикою засобами інших мов, ми встановили суттєву різницю між поняттями поетичного перекладу та відтворення.

Поетичний текст, трансформований засобами іншої мови, здобуває інші ознаки - він починає існувати на межі двох культур, стає своєрідним феноменом. Відтворення запобігає втраті культурних зв'язків, дозволяє уникнути втрат смислових складових значення БЛ у композиції поетичного тексту. Визначальним фактором у цьому процесі виступає композиційна роль БЛ у поетичному тексті, іiі значення як смислової домінанти в ієрархії СП твору.

У результаті перекладу безеквівалентних одиниць вірш починає існувати як текст іншого етносу, оскільки втрачає, а точніше сказати, змінює формальні показники етнокультурної належності, носіями яких виступає БЛ: Щоб він не плакав, не журивсь, Щоб він де-небудь прихиливсь, То оддадуть у москалі (Т. Шевченко). - ...Damit er weint nicht, nicht betrübt Und ohne Hausung bleibt - da gibt Man ihn zu den Soldaten fort! (H. Rodenberg).

Відтворення у нашому дослідженні - вид літературної творчості, коли поетичний текст, що існує в культурному середовищі певного етносу й відображає його національні особливості, картину світу, опиняється на грунті іншої культури зі збереженням тонкощів змісту, обра- 
зної системи, національної своєрідності, що проявляється на рівні існування БЛ. Тому носіями іншої мови сприймається як здобуток «чужої» культури: Der letzte bin ich auf dem Pfad Schwärmender Kosaken, Die Steppen schwinden vor der Stadt, - Tot sind die Tschumaken (Яків Щоголів, пер. H. Rodenberg). Німецькомовний читач, сприймаючи контекст, вважатиме ці БЛ екзотизмами іншої культури. Значення цих лексем, можливо, буде незрозуміле читачеві, але з'явиться важлива особливість - зв'язок із іншою культурою. Читач розуміє, що текст - «надбання» $з$ іншої культури. У тексті-відповіднику безеквівалентні одиниці іншої мови починають функціонувати як екзотизми чи варваризми, оскільки позначають предмети чи явища іншої дійсності. Поетичний текст починає існувати як феномен на межі двох культур, оскільки естетична реакція іншомовного реципієнта на ці образи значно відрізняється від реакції носіїв мови.

3 метою подолання смислових втрат при перекладі часто використовується заміна БЛ. Для відтворення національно-культурних рис іншої мови застосовують назви реалій зі своєї мови. Такий спосіб можливий лише в тому випадку, коли мови мають спільні або близькі суспільно-культурні чи національні особливості, а народи - схожий предметно-поняттєвий світ: На щуебінь часто ми до Сущзенка ходили. За цее платили нам щуоденно четвертак. Та по ночах дівчат в половниках любили... О свіжий дух степів, о поцілунків смак!.. (В. Сосюра). - Работать к Сущенку на щеебень мы ходили, - Случалось четвертак добыть нам в день иной. А в клунях по ночам мы девушек любили... О, почелуев вкус, о, свежий дух степной!.. (Н.Уиаков). Отже, українське слово «nоловник» - у російському варіанті «клуня». (Половник - місце, куди зсипають полову; засік для полови). (Клуня - молотильный сарай; укр. клуня - будівля для зберігання снопів, сіна, полови тощо, а також для молотьби, віяння та ін.).

Проблема відтворення національно характеристичної лексики засобами іншої мови ускладнюються ще й тим, що необхідно передати не тільки особливості певних побутових чи історичних реалій твору, але й донести до читача правильне розуміння усталених образів, що складаються в кожного народу протягом віків, знайти в мові такі засоби, які б достовірно відображали риси національної психіки народу - носія іншої мовИ.

Висновки та перспективи подальшого дослідження. 3'ясувавши теоретичні передумови використання в лінгвістиці терміну «безеквівалентна лексика», ми вважаємо, що безеквівалентна лексема - особлива одиниця, що відображає національно-культурну своєрідність мови на 
лексичному рівні, номінує такі явища у сфері певної культури, які не властиві іншим. БЛ - це складова образності тексту, яка несе емоційно-експресивний підтекст, пов'язаний з ідеоетнічним компонентом значення.

БЛ - смислова сильна позиція поетичної композиції, що й визначає специфіку іiї перекладу. Етнокультурний компонент семантики безеквівалентної лексеми $є$ універсальним і поширюється на смисл-зміст усього тексту, оскільки безеквівалентна лексична одиниця як сильна позиція вступає в суперструктурні зв'язки з іншими смисловими елементами поетичної композиції.

Наше дослідження стосувалося спостереження за особливостями відтворення БЛ в іншомовних текстах. Розглянувши різні способи передачі безеквівалентних лексичних одиниць у іншомовних текстах-відповідниках, констатуємо необхідність врахування значення окремої безеквівалентної лексеми як сильної позиції в композиції поетичного тексту. Дослідження значення БЛ як СП передбачає розгляд асиметричних зв'язків та смислових відношень цих лексичних одиниць із іншими структурними та смисловими СП тексту.

Зрозуміло, що процес перекладу БЛ треба розглядати, у першу чергу, як творчий процес, який дозволяє зберегти етнічну картину світу, не ігноруючи композиційної та смислової основи поетичного контексту.

\section{СПИСОК ВИКОРИСТАНОЇ ЛІТЕРАТУРИ}

1. Безобразова Л.Л. Язык и композиция лирического стихотворения (пособие для спецкурса) / Л.Л. Безобразова. - Полтава, 1992. - 74c.

2. Богаткіна Н. Внутрішня форма слова як прояв своєрідності національної мовної картини світу / Надія Богаткіна // Наукові записки. - Випуск XXVI. Серія : Філологічні науки (мовознавство). - Кіровоград : РВЦ КДПУ ім. В. Винниченка, 2000. - С.24-29.

3. Василько 3.С. Символізація значення слова в українському фольклорному мовленні (на матеріалі фауноназв у казках, піснях і пареміях) : автореф. дис. ... канд. філол. наук : 10.02.01 - українська мова / 3.С. Василько. - К., 2003. - 20с.

4. Волошина А. Безеквівалентна лексика близькоспоріднених мов: проблема семантичної структури / А. Волошина // Наукові записки. - Випуск XXVI. - Серія: Філологічні науки (мовознавство). - Кіровоград : РВЦ КДПУ ім. В. Винниченка, 2000. - С.56-64.

5. Дяченко Л.М. Функціонально-семантична характеристика безеквівалентної та фонової лексики сучасної української літературної мови: автореф. дис. ... канд. філол. наук : 10.02.01 - українська мова / Л.М. Дяченко. - К., 1997. - 18c.

6. Зайченко Н.Ф., Коваль-Костинська О.В., Паламарчук О.Л. Національно-культурний компонент мовної системи як перекладознавча проблема / Н.Ф. Зайченко та ін. // Мовознавство. - 1998. - № 2 - 3. - С.179 - 186. 
7. Кононенко В.І. Мова і народна культура / В.І. Кононенко // Мовознавство. - 2001. - №3. - С.62 - 70 .

8. Космеда Т.А. Денотат, конотація й аксіосемантика у проекції на лексико-семантичні відповідники російської та української мов / Т.А. Космеда // Мовознавство. - 1997. - № $4-5$. - С.58 - 63 .

9. Кочерган М.П. До питання про безеквівалентну лексику і лакуни та способи їх компенсації / М.П. Кочерган // Проблеми зіставної семантики. Збірник статей за доповідями Міжнародної наукової конференції з проблем зіставної семантики 23-25 вересня 1999р./ Відп. ред. М.П.Кочерган. - К., 1999. - С. 42 45.

10. Кремльова О.I. До питання про особливості функціонування мовних одиниць 3 національно-культурним компонентом у художньому тексті / О.І. Кремльова // Лінгвістичні дослідження. Зб. наук. праць. Випуск 2. - Харків, 1992. - С.83-86.

11. Мойсієнко А.К. Слово в аперцепційній системі поетичного тексту. Декодування шевченкового вірша: автореф. дис. ... докт. філол. наук : 10.02 .01 - українська мова / А.К. Мойсієнко. - К., 1997. - 32с.

12. Торсуева И.Г. Интонация и картина мира художественного текста / И.Г. Торсуева // Текст как отображение картины мира: Сборник научных трудов. - Выпуск 341. - М., 1989. - С.5-11.

13. Тупиця О.Ю. Явище безеквівалентності в лексичній системі мови: проблеми іншомовного відтворення / О.Ю. Тупиця // Рідне слово в етнокультурному вимірі: зб. наук. праць / Дрогобицький державний педагогічний університет імені Івана Франка. - Дрогобич: Посвіт, 2016. - С.200 - 213.

14. Форманова С.В. Ключові слова у мовній картині світу Михайла Коцюбинського: автореф. дис. ... канд. філол. наук : 10.02 .01 - українська мова / С.В. Форманова. - К., 1999. - 17с.

\section{REFERENCES}

1. Bezobrazova, L.L. (1992). Yazyk i kompozitsiya liricheskogo stikhotvoreniya (posobie dlya spetskursa) [Language and composition of the lyrical poem (manual for a special course)]. Poltava. [in Ukrainian]

2. Bohatkina, N. (2000). Vnutrishnia forma slova yak proiav svoieridnosti natsionalnoi movnoi kartyny svitu [The internal form of the word as a manifestation of the originality of the national language picture of the world]. Naukovi zapysky, XXVI. Seriia : Filolohichni nauky (movoznavstvo) - Proceedings. - Issue XXVI. - Series: Philological Sciences (Linguistics). Kirovohrad : RVTs KDPU im. V. Vynnychenka. [in Ukrainian]

3. Vasylko, Z.S. (2003). Symvolizatsiia znachennia slova v ukrainskomu folklornomu movlenni (na materiali faunonazv u kazkakh, pisniakh i paremiiakh) [Symbolization of the meaning of the word in Ukrainian folklore (on the material of faunonyms in fairy tales, songs and paremias)]. Extended abstract of candidate's thesis. Kyiv. [in Ukrainian]

4. Voloshyna, A. (2000). Bezekvivalentna leksyka blyzkosporidnenykh mov: problema semantychnoi struktury [Non-equivalent vocabulary of closely related 
languages: the problem of semantic structure]. Naukovi zapysky. - Vypusk XXVI. Seriia: Filolohichni nauky (movoznavstvo) - Proceedings. - Issue XXVI. - Series: Philological Sciences (Linguistics). Kirovohrad : RVTs KDPU im. V. Vynnychenka. [in Ukrainian]

5. Diachenko, L.M. (1997). Funktsionalno-semantychna kharakterystyka bezekvivalentnoi ta fonovoi leksyky suchasnoi ukrainskoi literaturnoi movy [Functional-semantic characteristic of the nonequivalent and background vocabulary of modern Ukrainian literary language]. Extended abstract of candidate's thesis. Kyiv. [in Ukrainian]

6. Zaichenko, N.F., Koval-Kostynska, O.V. \& Palamarchuk, O.L. (1998). Natsionalno-kulturnyi komponent movnoi systemy yak perekladoznavcha problema [The national-cultural component of the language system as a translation-related problem]. Movoznavstvo. - Linguistics, 2-3,179-186. [in Ukrainian]

7. Kononenko, V.I. (2001). Mova i narodna kultura [Language and folk culture]. Movoznavstvo - Linguistics, 3, 62 - 70. [in Ukrainian]

8. Kosmeda, T.A. (1997). Denotat, konotatsiia y aksiosemantyka u proektsii na leksyko-semantychni vidpovidnyky rosiiskoi ta ukrainskoi mov [Denotate, connotation and axiomsantics in projection into lexico-semantic correspondences of Russian and Ukrainian languages.]. Movoznavstvo - Linguistics, 4 - 5, 58 - 63. [in Ukrainian]

9. Kocherhan, M.P. (1999). Do pytannia pro bezekvivalentnu leksyku i lakuny ta sposoby yikh kompensatsii [To the question of the nonequivalent vocabulary and gaps and ways of their compensation]. Problemy zistavnoi semantyky. Zbirnyk statei za dopovidiamy Mizhnarodnoi naukovoi konferentsii z problem zistavnoi semantyky - Problems of comparable semantics. Collection of articles on the reports of the International scientific conference on the problems of comparative semantics (pp. 42-45). Kyiv. [in Ukrainian]

10. Kremlova, O.I. (1992). Do pytannia pro osoblyvosti funktsionuvannia movnykh odynyts z natsionalno-kulturnym komponentom u khudozhnomu teksti [On the question of the peculiarities of the functioning of linguistic units with the national-cultural component in the text of the text]. Linhvistychni doslidzhennia. Zb. nauk. prats - Linguistic research. Zb sciences works, 2, 83 - 86. Kharkiv. [in Ukrainian]

11. Moisiienko, A.K. (1997). Slovo v apertseptsiinii systemi poetychnoho tekstu. Dekoduvannia shevchenkovoho virsha: [The word in the apperception system of poetic text. Decoding Shevchenko's verse]. Extended abstract of candidate's thesis. Kyiv. [in Ukrainian]

12. Torsueva, I.G. (1989). Intonatsiya i kartina mira khudozhestvennogo teksta [Intonation and picture of the world of art text]. Tekst kak otobrazhenie kartiny mira: Sbornik nauchnykh trudov - Text as a mapping of the world: a collection of scientific works, 31, 5-11. Moscow [in Russian]

13. Tupytsya, O.Iu. (2016). Yavyshche bezekvivalentnosti v leksychnii systemi movy: problemy inshomovnoho vidtvorennia [The phenomenon of equivalence in the lexical system of language: problems of foreign language reproduction]. Ridne slovo v etnokulturnomu vymiri-Native word in ethnocultural terms. Drohobych: Posvit. [in Ukrainian]

14. Formanova, S.V. (1999). Kliuchovi slova u movnii kartyni svitu Mykhaila Kotsiubynskoho [Key words in the language picture of the world by Michael Kotsyubinsky]. Extended abstract of candidate's thesis. Kyiv. [in Ukrainian]

Стаття надійшла до редколегії 21.09.2017 p. 